\title{
How should we evaluate sweetened beverage tax policies? A review of worldwide experience
}

\author{
Shu Wen $\mathrm{Ng}^{1,2^{*}}$ (D) M. Arantxa Colchero ${ }^{3}$ and Martin White ${ }^{4}$
}

\begin{abstract}
Over 45 jurisdictions globally have implemented sweetened beverage taxes. Researchers and policymakers need to assess whether and how these taxes change beverage demand and supply, their intended and unanticipated health, economic and equity impacts. Lessons from such evaluations can maximise the policies' success and impact on non-communicable disease prevention globally. We discuss key theoretical, design and methodological considerations to help policymakers, funders and researchers commission and conduct rigorous evaluations of these policies and related disease prevention efforts. We encourage involving the perspectives of various stakeholders on what evaluations are needed given the specific context, what data and methods are appropriate, readily available or can be collected within time and budget constraints. A logic model /conceptual system map of anticipated implications across sectors and scales should help identify optimal study design, analytical techniques and measures. These models should be updated when synthesising findings across diverse methods and integrating findings across subpopulations using similar methods.
\end{abstract}

Keywords: Sugar-sweetened beverage, Tax, Evaluation, Policy, Logic models

\section{Background}

There is ample evidence showing that consumption of sweetened beverages is strongly and positively associated with the prevalence of non-communicable diseases (NCDs), including obesity, type 2 diabetes, cardiovascular diseases [1-3] and certain cancers [4, 5], as well as all-cause mortality [6]. Consumption and outcomes are socio-economically patterned and lead to health inequalities [7]. Consumption of these beverages is higher than recommended [8] and increasing, particularly in lowand middle-income countries [7]. In higher-income

\footnotetext{
*Correspondence: shuwen@unc.edu

${ }^{1}$ Carolina Population Center, University of North Carolina at Chapel Hill, CB \#8120, 137 East Franklin Street, Chapel Hill, NC 27516, USA

2Department of Nutrition, Gillings School of Global Public Health, University of North Carolina at Chapel Hill, CB\#7461, UNC-Chapel Hill, Chapel Hill, NC 27599-7461, USA

Full list of author information is available at the end of the article
}

countries, where there have been initial reductions in sugar-sweetened beverage consumption, these reductions have plateaued and the beverage industry is failing to meet its own pledges [9]. Effective regulations will be needed to discourage sweetened beverage consumption so as to contribute towards curtailing the pandemic of associated chronic NCDs and obesity. If not tackled, these diseases will continue to have severe consequences for healthcare systems and economic development. Poorer individuals will generally bear the greatest burden of associated morbidity and mortality $[10,11]$. In recognition of these challenges, there is growing global momentum to use pricing policies, such as sweetened beverage taxes, as a key intervention to help address the global NCD pandemic, make progress towards achieving the Sustainable Development Goals [12] and reduce inequities $[10,13-16]$. These efforts have been backed by

(c) The Author(s). 2021 Open Access This article is licensed under a Creative Commons Attribution 4.0 International License, which permits use, sharing, adaptation, distribution and reproduction in any medium or format, as long as you give appropriate credit to the original author(s) and the source, provide a link to the Creative Commons licence, and indicate if changes were made. The images or other third party material in this article are included in the article's Creative Commons licence, unless indicated otherwise in a credit line to the material. If material is not included in the article's Creative Commons licence and your intended use is not permitted by statutory regulation or exceeds the permitted use, you will need to obtain permission directly from the copyright holder. To view a copy of this licence, visit http://creativecommons.org/licenses/by/4.0/ The Creative Commons Public Domain Dedication waiver (http://creativecommons.org/publicdomain/zero/1.0/) applies to the data made available in this article, unless otherwise stated in a credit line to the data. 
an abundance of academic studies, systematic reviews and meta-analyses [17-21].

As these sweetened beverage taxes are passed and implemented [22], it is important to assess whether and in what ways the various forms of these policies contribute towards changing consumer demand and industry supply of beverages, their intended and unanticipated health, economic, equity and broader wellbeing impacts, and what improvements may be made to strengthen and maximise the their success. This requires rigorously planned and executed evaluations.

In this article, rather than provide a review of the findings of existing evaluations [23, 24], we ask: what are the lessons we can learn from sweetened beverage tax evaluations that can help improve future evaluations and thus support NCD and obesity prevention efforts? To this end, we offer an overview of progress in the field and an analysis of key theoretical, design and methodological considerations, recognizing that it is unlikely that any single evaluation of sweetened beverage taxes will be fully comprehensive given data, resource and time constraints. As such, we do not seek to elevate one evaluation approach over others or rank them, rather we hope to describe the various trade-offs and constraints under which such realworld evaluations function under and thus the issues potential evaluators should consider given their particular context and circumstances. We limit our narrative review to existing evaluations where: there has been a clear declaration of interests which demonstrates that the research team is fully independent and has no conflicts of interest with regard to the findings; and where a scientific or advisory committee have been formed to provide independent oversight of the evaluation [25].

\section{Understanding sweetened beverage tax policies}

Understanding the characteristics and nuances of sweetened beverage tax policy designs, including their genesis, development, political context, and stakeholder involvement in influencing their goals and design, form the backbone for developing an evaluation approach. Table 1 provides selected examples from over 45 jurisdictions that have implemented such taxes as of August 2021 [22], illustrating the different types of sweetened beverage tax structures, regulatory designs and their explicit and implicit goals to illustrate how and why these are important.

Tax structure and design critically informs evaluation design and reflects the primary objectives of the tax. Who the tax is levied on (e.g., large vs small vs all manufacturers/distributors, large, vs small vs all retailers, or consumers) will determine the research questions and the types of data needed. Additionally, whether the tax is ad valorem (percentage-based) or specific (unit-based), and what the chosen tax base is (e.g., value-added, pretax price, volume, sugar-content) determine the measures to track. The tax design also matters in terms of how it (dis)incentivises changes. For example, is the tax a flat rate (e.g., $10 \%$ as in Barbados or 1 cent/ounce, as in Berkeley California), a linear rate (e.g., as in South Africa) or multi-tiered (e.g., as in the UK)? For flat-rate taxes, monitoring changes in prices, sales and/or purchases might suffice, but researchers should consider, theorise and monitor alternative ways that industry may respond (e.g., shrinking package sizes while maintaining or increasing price, strategic cost shifting across beverage types and size offerings, marketing and promotions). For taxes based on sugar content, it will be important also to monitor changes in sugar content of products (reformulation), manufacturers' portfolios (e.g., product innovation, changes in package sizes) by sugar concentration and marketing of their products including labelling and claims, and promotions based on price or volume.

Also, does the tax apply to $100 \%$ juices, milk-based drinks, alcoholic drinks (alcopops) and artificially sweetened beverages? For sugar-concentration based taxes, do these apply to products with intrinsic sugar (e.g., dairy, fruit juices)? Data on the distribution of sales by type of beverages can help in designing a tax that covers all potential substitute drinks. It also provides valuable information on the potential untaxed beverages (e.g., water, plain milks) that could be substitutes and will need monitoring. The definition of products included versus excluded from the tax also then needs to be matched with evaluation data with sufficient detail to classify products appropriately since misclassification of taxed products as non-taxed (or vice-versa) will bias results.

The geographical jurisdiction of the tax policy may impact on the extent to which cross-border shopping might exist. Generally, the smaller the political or physical geographical scope, the more attention should be paid to monitoring cross-border behaviours of consumers, distributors and retailers.

The framing around the purpose of the tax and how the tax policy is made known to the public by legislators and advocates also has implications for the evaluation design. On the first point, there may be multiple objectives of sweetened beverage taxes, such as lowering sweetened beverage consumption, improving health, generating revenue for general uses or specific uses like health promotion and/or early childhood education. The political context and public opinion or support likely drives this framing, and the name of the tax policy can help convey the chosen framing. For example, in the UK, the term "Soft Drinks Industry Levy" (SDIL) conveys that the levy is placed on industry and that the 
Table 1 Examples of sweetened beverage tax structures, designs and their goals

\begin{tabular}{|c|c|c|c|c|c|c|c|c|}
\hline \multirow{2}{*}{$\begin{array}{l}\text { Tax } \\
\text { design }\end{array}$} & \multirow{2}{*}{$\begin{array}{l}\text { Levied on/ } \\
\text { collected } \\
\text { from [goes } \\
\text { to] }[22,26]\end{array}$} & \multicolumn{7}{|c|}{ Example where implemented } \\
\hline & & Location & $\begin{array}{l}\text { Dates [22, } \\
26]\end{array}$ & $\begin{array}{l}\text { Taxable } \\
\text { categories } \\
\text { definitions [22, } \\
26]\end{array}$ & $\begin{array}{l}\text { Exempted } \\
\text { products/ } \\
\text { Categories } \\
{[22,26]}\end{array}$ & $\begin{array}{l}\text { Tax rate/level } \\
{[22,26]}\end{array}$ & $\begin{array}{l}\text { Stated } \\
\text { purpose }\end{array}$ & Framing \\
\hline $\begin{array}{l}\text { Ad } \\
\text { valorem }\end{array}$ & $\begin{array}{l}\text { Excise on } \\
\text { distributors, } \\
\text { importers \& } \\
\text { manufacturers } \\
\text { [general } \\
\text { budget] }\end{array}$ & $\begin{array}{l}\text { Barbados [27] } \\
\text { [national] }\end{array}$ & $\begin{array}{l}\text { Announced: } \\
\text { June } 2015 \\
\text { Implemented: } \\
1 \text { September } \\
2015\end{array}$ & $\begin{array}{l}\text { Carbonated soft } \\
\text { drinks, juice } \\
\text { drinks, sports } \\
\text { drinks, fruit juices } \\
\text { that contain } \\
\text { added high } \\
\text { calorie } \\
\text { sweeteners } \\
\text { based on } \\
\text { Harmonized } \\
\text { System (HS) tariff } \\
\text { codes }\end{array}$ & $\begin{array}{l}\text { - } 100 \% \text { juices } \\
\text { - Powders and } \\
\text { concentrates } \\
\text { - Sugar } \\
\text { sweetened } \\
\text { dairy/milks }\end{array}$ & $\begin{array}{l}10 \% \text { of value/ } \\
\text { price that } \\
\text { manufacturer/ } \\
\text { distributors } \\
\text { charge retailers. }\end{array}$ & $\begin{array}{l}\text { Address the } \\
\text { high burden of } \\
\text { non- } \\
\text { communicable } \\
\text { diseases in } \\
\text { Barbados [27] }\end{array}$ & $\begin{array}{l}\text { Revenue } \\
\text { generation } \\
\text { Reduce } \\
\text { consumption of } \\
\text { taxed beverages } \\
{[27]}\end{array}$ \\
\hline $\begin{array}{l}\text { Ad } \\
\text { valorem }\end{array}$ & $\begin{array}{l}\text { Goods and } \\
\text { Services Tax } \\
\text { (GST) collected } \\
\text { at point of } \\
\text { purchase } \\
\text { [general } \\
\text { budget] }\end{array}$ & $\begin{array}{l}\text { India [28] } \\
\text { [national] }\end{array}$ & $\begin{array}{l}\text { Implemented: } \\
1 \text { July } 2017\end{array}$ & $\begin{array}{l}\text { Aerated drinks } \\
\text { and lemonades } \\
\text { based on HS } \\
\text { tariff code }\end{array}$ & $\begin{array}{l}\text { - } 100 \% \text { juices } \\
\text { - Powders and } \\
\text { concentrates } \\
\text { - Sugar } \\
\text { sweetened } \\
\text { dairy/milks } \\
\text { - Other non- } \\
\text { aerated } \\
\text { drinks with } \\
\text { added sugar }\end{array}$ & $\begin{array}{l}\text { Aerated drinks } \\
\text { and lemonades } \\
\text { (40\%: from 12\% } \\
\text { GST on all } \\
\text { processed } \\
\text { packaged } \\
\text { foods/ } \\
\text { beverages + } \\
28 \% \text { GST on sin } \\
\text { goods) }\end{array}$ & $\begin{array}{l}\text { Simplify tax } \\
\text { structure of } \\
\text { prior } \\
\text { Central VAT + } \\
\text { State VAT, and } \\
\text { eliminate } \\
\text { cascading } \\
\text { taxes [28] }\end{array}$ & $\begin{array}{l}\text { Improve tax } \\
\text { collection and } \\
\text { revenue } \\
\text { generation [28] }\end{array}$ \\
\hline $\begin{array}{l}\text { Specific - } \\
\text { Volume }\end{array}$ & $\begin{array}{l}\text { Excise on } \\
\text { distributors, } \\
\text { importers \& } \\
\text { manufacturers } \\
\text { [general } \\
\text { budget] }\end{array}$ & $\begin{array}{l}\text { Mexico [29] } \\
\text { [national] }\end{array}$ & $\begin{array}{l}\text { Implemented: } \\
1 \text { Jan } 2014\end{array}$ & $\begin{array}{l}\text { All non-alcoholic } \\
\text { beverages with } \\
\text { added sugar in- } \\
\text { cluding reconsti- } \\
\text { tuted powdered } \\
\text { sugar-sweetened } \\
\text { drinks and fla- } \\
\text { voured/sweet- } \\
\text { ened dairy } \\
\text { products that are } \\
\text { not milks }\end{array}$ & $\begin{array}{l}\text { - Milk products } \\
\text { (milk is the } \\
\text { primary/first } \\
\text { ingredient) } \\
\text { - } 100 \% \text { fruit } \\
\text { and/or } \\
\text { vegetable } \\
\text { juice }\end{array}$ & $\begin{array}{l}1 \text { Mexican Peso } \\
\text { per ready-to- } \\
\text { drink litre } \\
\text { Indexed to } \\
\text { inflation once } \\
\text { cumulative } \\
\text { inflation hits } \\
10 \%\end{array}$ & $\begin{array}{l}\text { Address high } \\
\text { prevalence of } \\
\text { diabetes and } \\
\text { cardiovascular } \\
\text { diseases in } \\
\text { Mexico [29] }\end{array}$ & $\begin{array}{l}\text { Reduce } \\
\text { consumption of } \\
\text { taxed beverages } \\
{[29]}\end{array}$ \\
\hline $\begin{array}{l}\text { Specific - } \\
\text { Volume }\end{array}$ & $\begin{array}{l}\text { Excise on } \\
\text { distributors, } \\
\text { importers \& } \\
\text { manufacturers } \\
\text { [Office of } \\
\text { education and } \\
\text { general } \\
\text { budget] }\end{array}$ & $\begin{array}{l}\text { Philadelphia } \\
\text { County/City } \\
\text { in } \\
\text { Pennsylvania, } \\
\text { United States } \\
\text { [30] } \\
\text { [City Council } \\
\text { vote] }\end{array}$ & $\begin{array}{l}\text { Enacted: } 16 \\
\text { June } 2016 \\
\text { Implemented: } \\
1 \text { Jan } 2017\end{array}$ & $\begin{array}{l}\text { - Bottled } \\
\text { beverages } \\
\text { - Syrups/ } \\
\text { concentrates } \\
\text { for commercial } \\
\text { sale } \\
\text { - Fruit/vegetable } \\
\text { drinks with } \\
\text { added sugar } \\
\text { - Mixers } \\
\text { - Coffee syrups } \\
\text { distributed to } \\
\text { coffee shops } \\
\text { - Beverages } \\
\text { containing } \\
\text { sweeteners that } \\
\text { are only non- } \\
\text { caloric ("diet } \\
\text { drinks") }\end{array}$ & $\begin{array}{l}\text { - Milk products } \\
\text { (milk is the } \\
\text { primary/first } \\
\text { ingredient) } \\
\text { - 100\% fruit } \\
\text { and/or } \\
\text { vegetable } \\
\text { juice } \\
\text { - Syrups, } \\
\text { concentrates, } \\
\text { and powders } \\
\text { sold to } \\
\text { consumers } \\
\text { - Natural or } \\
\text { common } \\
\text { sweeteners } \\
\text { that are not } \\
\text { already in } \\
\text { beverages }\end{array}$ & $\begin{array}{l}\text { US } \$ 0.015 \text { per } \\
\text { ounce on retail } \\
\text { sale on ready- } \\
\text { to-drink vol- } \\
\text { umes of taxable } \\
\text { beverages } \\
\text { Not indexed to } \\
\text { inflation }\end{array}$ & $\begin{array}{l}\text { None } \\
\text { Earmark not in } \\
\text { ordinance but } \\
\text { in mayor's } \\
\text { budget [26]. }\end{array}$ & $\begin{array}{l}\text { Revenue } \\
\text { generation to } \\
\text { support new or } \\
\text { expanded } \\
\text { programs } \\
\text { including Pre-k } \\
\text { access and Re- } \\
\text { build (for park, } \\
\text { community } \\
\text { centre, and li- } \\
\text { brary repairs) } \\
\text { [26]. }\end{array}$ \\
\hline $\begin{array}{l}\text { Specific - } \\
\text { Volume } \\
\text { tax } \\
\text { based on } \\
\text { sugar } \\
\text { concentr- } \\
\text { ation } \\
\text { threshold }\end{array}$ & $\begin{array}{l}\text { Excise on } \\
\text { distributors, } \\
\text { importers \& } \\
\text { manufacturers } \\
\text { (exempt } \\
\text { producers } \\
\text { with }<1 \\
\text { million litres/ } \\
\text { year) } \\
\text { [general }\end{array}$ & $\begin{array}{l}\text { United } \\
\text { Kingdom [31] } \\
\text { [national] }\end{array}$ & $\begin{array}{l}\text { Announced: } \\
\text { March } 2016 \\
\text { Public } \\
\text { Consultation: } \\
\text { Aug } 2016 \\
\text { Implemented: } \\
6 \text { April } 2018\end{array}$ & $\begin{array}{l}\text { All packaged } \\
\text { beverages that } \\
\text { contain sugar } \\
\text { added during } \\
\text { production of at } \\
\text { least } 5 \mathrm{~g} \text { of sugar } \\
\text { per } 100 \mathrm{ml} \text { in } \\
\text { ready to drink } \\
\text { form }\end{array}$ & $\begin{array}{l}\text { - Drinks with } \\
\geq 75 \% \text { milk } \\
\text { - Milk } \\
\text { replacement } \\
\text { drinks (e.g. } \\
\text { plant based } \\
\text { 'milks') } \\
\text { - Alcohol } \\
\text { replacement } \\
\text { drinks (with }\end{array}$ & $\begin{array}{l}£ 0.18 \text { per litre } \\
\text { for drinks } \\
\text { containing at } \\
\text { least } 5 \mathrm{~g} \text { of } \\
\text { sugar per } 100 \\
\mathrm{ml} \\
£ 0.24 \text { per litre } \\
\text { for drinks with } \\
\text { more than } 8 \mathrm{~g} \\
\text { per } 100 \mathrm{ml} \text {. }\end{array}$ & $\begin{array}{l}\text { Reduce } \\
\text { childhood } \\
\text { obesity by } \\
\text { removing } \\
\text { added sugar } \\
\text { from soft } \\
\text { drinks [31]. } \\
\text { Encourage soft } \\
\text { drink } \\
\text { producers and }\end{array}$ & $\begin{array}{l}\text { Reformulations } \\
\text { Reduce sugar } \\
\text { consumption } \\
\text { from beverages } \\
\text { Fund children's } \\
\text { health initiatives } \\
\text { (e.g., school } \\
\text { sports and } \\
\text { healthy school } \\
\text { breakfast clubs) }\end{array}$ \\
\hline
\end{tabular}


Table 1 Examples of sweetened beverage tax structures, designs and their goals (Continued)

\begin{tabular}{|c|c|c|c|c|c|c|c|c|}
\hline \multirow{2}{*}{$\begin{array}{l}\text { Tax } \\
\text { design }\end{array}$} & \multirow{2}{*}{$\begin{array}{l}\text { Levied on/ } \\
\text { collected } \\
\text { from [goes } \\
\text { to] }[22,26]\end{array}$} & \multicolumn{7}{|c|}{ Example where implemented } \\
\hline & & Location & $\begin{array}{l}\text { Dates [22, } \\
26]\end{array}$ & $\begin{array}{l}\text { Taxable } \\
\text { categories } \\
\text { definitions [22, } \\
26]\end{array}$ & $\begin{array}{l}\text { Exempted } \\
\text { products/ } \\
\text { Categories } \\
{[22,26]}\end{array}$ & $\begin{array}{l}\text { Tax rate/level } \\
{[22,26]}\end{array}$ & $\begin{array}{l}\text { Stated } \\
\text { purpose }\end{array}$ & Framing \\
\hline & budget] & & & & $\begin{array}{l}\text { alcohol by } \\
\text { volume < } \\
0.5 \%) \\
\text {-100\% fruit/ } \\
\text { veg juices } \\
\text { - Liquid drink } \\
\text { flavouring } \\
\text { added to } \\
\text { food/drinks } \\
\text { - Powders } \\
\text { mixed into } \\
\text { liquids and } \\
\text { served in } \\
\text { open } \\
\text { container }\end{array}$ & & $\begin{array}{l}\text { importers to } \\
\text { [31]: } \\
\text { - reformulate } \\
\text { to cut sugar } \\
\text { content } \\
\text { - reduce } \\
\text { portion sizes } \\
\text { of added } \\
\text { sugar drinks } \\
\text { - import } \\
\text { reformulated } \\
\text { drinks with } \\
\text { less sugar }\end{array}$ & [31] \\
\hline $\begin{array}{l}\text { Specific - } \\
\text { Sugar } \\
\text { content } \\
\text { based }\end{array}$ & $\begin{array}{l}\text { Excise on } \\
\text { distributors, } \\
\text { importers \& } \\
\text { manufacturers } \\
\text { (exempt } \\
\text { producers } \\
\text { with }<50 \mathrm{~K} \\
\text { liters/yr) } \\
\text { [general } \\
\text { budget] }\end{array}$ & $\begin{array}{l}\text { South Africa } \\
\text { [32] [national] }\end{array}$ & $\begin{array}{l}\text { Policy paper } \\
\text { for public } \\
\text { consultation: } \\
\text { July } 2016 \\
\text { Draft } \\
\text { legislation: } \\
\text { Feb } 2017 \\
\text { Enacted: Dec } \\
2017 \\
\text { Implemented: } \\
1 \text { April } 2018\end{array}$ & $\begin{array}{l}\text { Based on } \\
\text { Harmonised } \\
\text { System (HS) tariff } \\
\text { codes } \\
\text { - Syrups and } \\
\text { concentrates } \\
\text { - Cocoa powder } \\
\text { and milk } \\
\text { extracts } \\
\text { - Non-alcoholic } \\
\text { waters, mineral, } \\
\text { aerated or } \\
\text { juices, with } \\
\text { sugar or } \\
\text { flavouring } \\
\text { - Non-alcoholic } \\
\text { beer }\end{array}$ & $\begin{array}{l}\text { - Milk products } \\
\text { (milk is the } \\
\text { primary/first } \\
\text { ingredient) } \\
\text {-100\% fruit } \\
\text { and/or } \\
\text { vegetable } \\
\text { juice }\end{array}$ & $\begin{array}{l}2.1 \text { SA cents per } \\
\text { gram of sugar } \\
\text { in excess of } 4 \\
\text { g/ } 100 \mathrm{ml} \text { based } \\
\text { on ready-to- } \\
\text { drink (reconsti- } \\
\text { tuted) form } \\
\text { Products in } \\
\text { taxable HS } \\
\text { category with } \\
\text { no sugar } \\
\text { information will } \\
\text { be taxed based } \\
\text { on default of } \\
20 \mathrm{~g} \text { of sugar/ } \\
100 \mathrm{ml} \text { in } \\
\text { reconstituted } \\
\text { form } \\
\text { Indexed to } \\
\text { inflation }\end{array}$ & $\begin{array}{l}\text { Address high } \\
\text { prevalence of } \\
\text { diabetes, } \\
\text { obesity and } \\
\text { cardiovascular } \\
\text { diseases [32, } \\
\text { 33] }\end{array}$ & $\begin{array}{l}\text { Reduce sugar } \\
\text { consumption } \\
\text { from beverages } \\
{[32]}\end{array}$ \\
\hline $\begin{array}{l}\text { Specific - } \\
\text { Sugar } \\
\text { type } \\
\text { based }\end{array}$ & $\begin{array}{l}\text { Excise on } \\
\text { distributors, } \\
\text { importers \& } \\
\text { manufacturers } \\
\text { [general } \\
\text { budget] }\end{array}$ & $\begin{array}{l}\text { Philippines } \\
\text { [34] [national] }\end{array}$ & $\begin{array}{l}\text { Enacted: } 19 \\
\text { Dec } 2017 \\
\text { Implemented: } \\
1 \text { Jan } 2018\end{array}$ & $\begin{array}{l}\text { Sweetened pre- } \\
\text { packaged: } \\
\text { - Sweetened } \\
\text { juice drinks } \\
\text { - Sweetened tea } \\
\text { - All carbonated } \\
\text { beverages } \\
\text { - Flavoured water } \\
\text { - Energy and } \\
\text { sports drinks } \\
\text { - Powdered } \\
\text { drinks not } \\
\text { classified as } \\
\text { milk, juice, tea } \\
\text { or coffee } \\
\text { - Cereal /grain } \\
\text { beverages } \\
\text { - Other non- } \\
\text { alcoholic bever- } \\
\text { ages with } \\
\text { added sugar }\end{array}$ & $\begin{array}{l}\text { - All milk } \\
\text { products, } \\
\text { whether } \\
\text { powdered or } \\
\text { in liquid } \\
\text { form, } \\
\text { sweetened or } \\
\text { not } \\
\text { - 3-in-1 coffee } \\
\text { packs } \\
\text { - 100\% fruit } \\
\text { and } \\
\text { vegetable } \\
\text { juices } \\
\text { - beverages } \\
\text { sweetened } \\
\text { with stevia or } \\
\text { coconut } \\
\text { sugar. }\end{array}$ & $\begin{array}{l}\text { Drinks with } \\
\text { caloric and } \\
\text { non-caloric } \\
\text { sweeteners will } \\
\text { be taxed } 6 \mathrm{Ph} \\
\text { Peso per litre. } \\
\text { Drinks with } \\
\text { high-fructose } \\
\text { corn syrup } \\
\text { taxed at } 12 \text { Ph } \\
\text { Peso per litre. } \\
\text { Not indexed to } \\
\text { inflation }\end{array}$ & $\begin{array}{l}\text { Generate } \\
\text { revenue and } \\
\text { fight obesity } \\
\text { and diabetes } \\
\text { and poor } \\
\text { dental health } \\
\text { Part of larger } \\
\text { Tax Reform for } \\
\text { Acceleration } \\
\text { and Inclusion } \\
\text { (TRAIN) Law } \\
\text { [34] }\end{array}$ & $\begin{array}{l}\text { Health measure } \\
\text { to addressed } \\
\text { poor oral health } \\
\text { which results in } \\
\text { poor school } \\
\text { attendance and } \\
\text { poor nutrition } \\
\text { Improve tax } \\
\text { collection and } \\
\text { revenue } \\
\text { generation [34] }\end{array}$ \\
\hline
\end{tabular}

primary purpose is to encourage supply-side changes (rather than to change the public's behaviour). This means that the evaluation design should likewise prioritize careful monitoring of industry responses
$[31,35]$. On the second point, how the tax is made known has implications particularly around the salience of the tax policy and signalling effects [36]. In the case of sweetened beverage taxes, higher salience 
likely promotes both consumer demand and supply changes.

Finally, from a policy perspective, while a sweetened beverage tax is typically one of the first food policies to be considered for addressing and preventing NCDs and obesity in any jurisdiction, it is often not the only policy considered. The timing and sequence of policies should be considered carefully as this will have implications for evaluation. For example, when policies are implemented together or in close succession, then it becomes challenging to measure the impact of each policy, so it would be important to consider what analytical approach makes sense for multi-intervention type evaluations to better distinguish the effects of each.

\section{Evaluation stages and considerations}

Because sweetened beverage tax policy development, legislation and implementation are events in complex adaptive systems, it is beneficial to take a logical, sequential and systemic approach to considering evaluation. This includes assessing the evaluability of the policy; theorizing the policy's impacts across sectors and scales (micro vs macro), as well as theorising both intended and unintended consequences from a public health perspective (e.g., product innovation or additional marketing that avoids the tax, but has the potential to worsen or harm health); identifying the optimal study design, analytical techniques, data and measures; and bringing the various components of work back together via interpretation, synthesis and integration.

Figure 1 illustrates graphically the key stakeholders that need to be engaged in evaluation efforts, the challenges they present to researchers and evaluations and, for each constituency, the potential for impacts of a sweetened beverage tax and related potential data sources. We refer to this further in the sections below. Our view is that engaging stakeholders in all aspects of a study, from conception, through design to execution, interpretation and knowledge exchange is critically important to ensuring the research is grounded in reality.

\section{Assessing Evaluability}

Before researchers, policymakers or funders move on evaluating policies or interventions, it is beneficial to

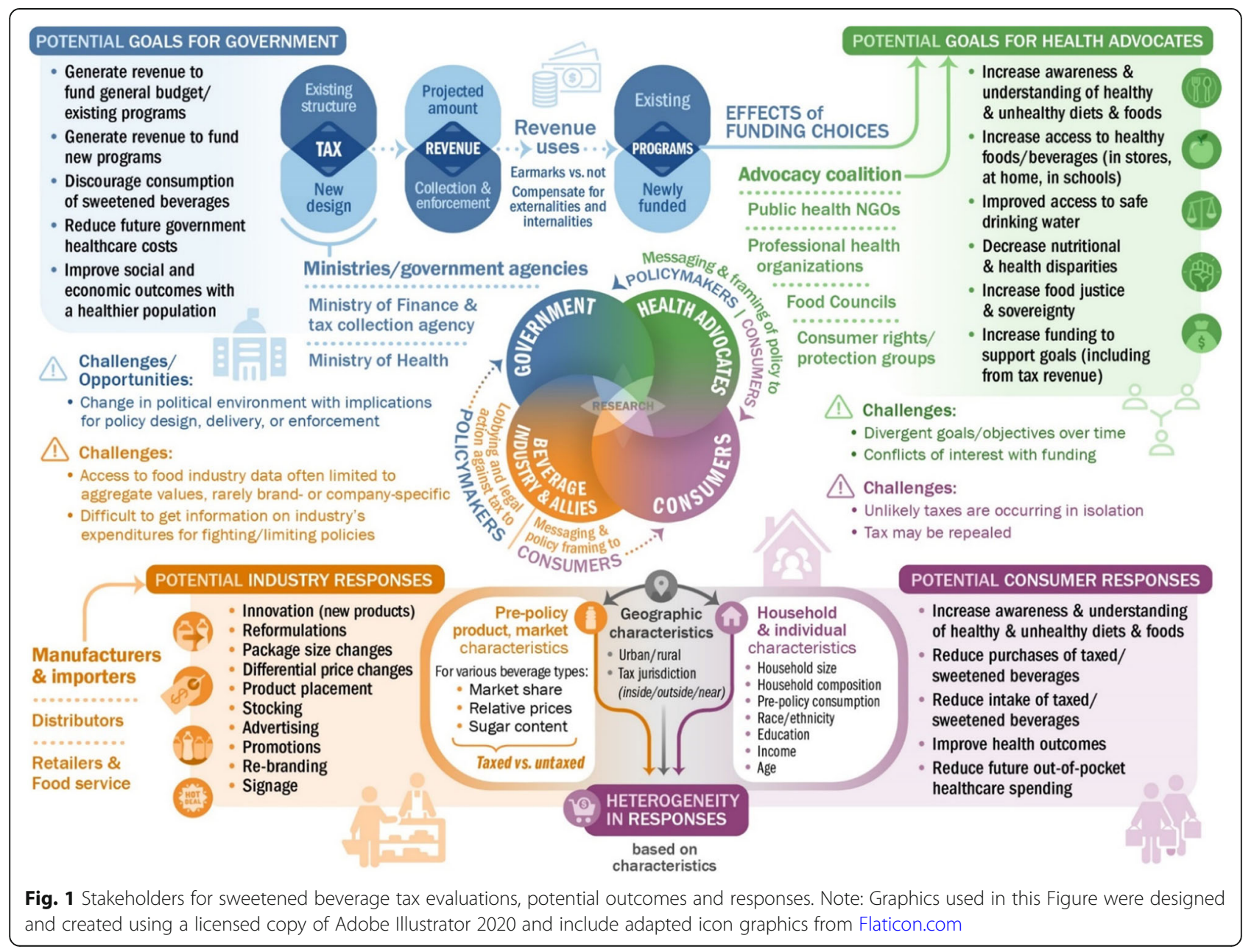


undertake an evaluability assessment to determine the extent to which an evaluation is feasible and build consensus among stakeholders (central section of Fig. 1) about the need, value and purposes of evaluative research [37]. Evaluability assessment is critical for the process of prioritising research questions together with stakeholders. In undertaking evaluability assessment, it helps to consider the following five questions, proposed by Ogilvie et al. [38]. Resolving these uncertainties will help to ensure the conduct of a viable and worthwhile evaluation:

1) Where is this policy/intervention situated within an overall (NCD prevention) program/strategy?

2) How will an evaluation study of this policy/ intervention affect policy decisions?

3) What are the plausible sizes and distribution of the policy's/intervention's hypothesized impacts?

4) How will the findings of an evaluation study add value to the existing scientific evidence?

5) Is it practical to evaluate the policy/intervention in the time available?

\section{Developing a conceptual understanding of the tax policy}

Understanding the dynamic systems that the sweetened beverage tax is likely to affect and hypothesising potential impacts across sectors and populations is an important first step. This can be supported by conceptual system mapping, developing a programme theory or logic model, or another form of causal diagram (e.g., a directed acyclic graph, DAG) [39-41]. In undertaking this process, it helps to engage with complexity theory and systems thinking, to theorise fully the range of possible reactions and counteractions that the policy will stimulate, especially from industry [42].

Involving multiple stakeholders (Fig. 1) in such activities via deliberative processes helps to ground conceptual thinking in the present context and build trust in the evaluative process. This can take the form of key informant interviews, focus groups, content and media analyses of public and trade press around the framing of the issues, review of legal documents, potential data or leaked documents on industry's lobbying, legal or other subversive strategies or actions [43], and consensus building processes (e.g., using community-based participatory research methods, Delphi studies or group model building activities). One example is a conceptual mapping process and Delphi study conducted in the UK to support evaluation of the SDIL [44]. Another example is a qualitative assessment of the tax passed, implemented and then repealed in Cook County Illinois [45].

Key informants might include technical and political staff at revenue agencies and ministries (e.g., finance, commerce/trade and industry, health) who have interests or involvement in the tax, those in food industry (manufacturers, retailers, food service sector), public health professionals (e.g., professional organizations, local food councils) and advocates (e.g., public health advocacy coalitions, consumer rights groups), and of course the public (especially those most affected by NCDs). Among the public, it will be instructive to consider various subsamples based on socio-demographic characteristics, political persuasion or other characteristics that might influence awareness of the proposed or implemented tax, understanding of tax (e.g., rate, scope), support of the tax or anticipated response to the tax [46]. Depending on the framing of the tax policy (central portion of Fig. 1), other key proponents might include those who could benefit from the tax revenue (e.g., school board members, teachers, parents), while other key opponents might include individuals who may perceive becoming disadvantaged (e.g., distributor or retail employees, advertising agencies, sugar producers).

The messaging around the tax among both those for and against the policy requires careful analysis to understand the underlying concerns and potential reactive strategies among stakeholders. Very often contextual factors such as the degree of trust in the government, agencies and politicians, the degree of coherence and coordination among those on each side of the issue, and concerns around food sovereignty, equity and policy efficiency deserve careful attention [47, 48]. Moreover, such analyses may uncover new perspectives or angles that researchers may not have considered. How a policy is framed by legislators and others can impact the public's responses to a tax; for example, a policy framed to address key public concerns (e.g. use of revenue or equity) could better garner public support and incentivize behavioural change [49], compared to one viewed as increasing burden to the public due to mismanagement of resources [45]. Given the likely disparate viewpoints from various stakeholders, researchers should also develop a communications plan in the early stages of designing an evaluation to minimize distraction.

\section{Choosing the optimal study design and analytical techniques}

Process evaluation Research to assess the adoption, extent and fidelity of implementation of a tax should be considered part of an evaluation effort, especially when the tax structure is complex. Process evaluation allows us to complement outcome and impact evaluation by assessing why a tax policy has achieved its intended impacts or not, as well as to assess for whom the policy is beneficial or otherwise, and under what circumstances [50]. This includes assessing whether there is clear language and guidance on who the tax should be collected 
from and how frequently, which products are taxed, how the tax is calculated, what the penalties are, the timeline for implementation, how tax revenue use is being determined and which government entities are charged with conducting and overseeing and inform/communicate to the affected industries and the public about the tax collection, reporting, enforcement and revenue use (upper sections of Fig. 1 - in blue and green). Moreover, the role and engagement of other stakeholders like the beverage industry and its allies (e.g., trade associations), distributors and retailers, and public health advocates in each jurisdiction and how they interacted with the media to frame their positions to the public and to policymakers also matters (middle section of Fig. 1). Implementation science approaches such as Consolidated Framework for Implementation Research are useful for uncovering what nuanced on-the-ground factors may matter, such as what has been done in understanding the enablers of success (and room for improvement) in Berkeley California [51] and causes of failure in Cook Country Illinois [45].

Natural experimental evaluation methods Since sweetened beverage taxes are implemented at some level of administrative jurisdiction, natural experimental methods are likely the most appropriate approaches to use for evaluation; and how they are applied will be a function of available data [52]. These can be used for assessing both micro-level outcomes like individual intake or household purchases [23], and macro-level outcomes like un/employment or revenue generation and use [53]. There is a substantial literature that describes these methods and how the various approaches available can help strengthen causal inferences [54-57]. Table 2 lays out some of the key analytical designs (differencein-differences, interrupted time series, regression discontinuity), statistical approaches (propensity scoring, correlated random effects), and examples where they have been used. Robustness checks, sensitivity analyses and, if possible, analyses using different data sets and considering different time frames are recommended to ensure that the results are stable and will not vary wildly when minor changes are made to how definitions are operationalized and to ensure that results are not being driven by outliers or choice of comparison population or sites.

Simulation methods Simulation models serve as important adjuncts to empirical evaluations, particularly for more distal or longer-term outcomes such as lowering NCD prevalence and mortality, healthcare cost savings, how these may vary across lower vs higher income populations [64], as well as macro-economic factors (e.g., employment or revenue use) [65]. Simulation modelling can be helpfully combined with empirical evaluation and is especially powerful when measured intermediate outcomes (e.g., changes in purchasing or consumption) are used to parameterise models. Simulation models also allow for comparison of various policy options. In fact, much of the earlier evidence used to make the case for sweetened beverage taxes was based on using demand system models [66], life tables [67], microsimulations $[68,69]$, extended cost-effectiveness analyses [70], or input-output models [71] under various scenarios.

Some industrial organization (IO) approaches that use parametric or semi-parametric models to simulate beverage demand and supply jointly are also useful to consider [72]. These models consider how firms may respond to taxes via price changes given their market share across beverage types and also how the public would thus change their purchases or intake to reach new equilibriums [73]. With the implementation of sweetened beverage taxes in some jurisdictions, it is now possible to validate these models and, if they perform well, these models can then be used for simulating higher rates or different policy designs. Table 3 lays out some of the key simulation-based methods and examples of how and where they have been applied.

\section{Identifying the appropriate outcome measures, data and timing}

While determining the optimal analytical methods, researchers need also simultaneously to consider potential outcome measures and understand what data are available. Figure 1 illustrates what the potential goals of government and health advocates and potential responses by the beverage industry and consumers might be. For example, the revenue generated from the tax (a potential goal by government) could be used in ways that create multiplier effects for the economy or help narrow existing health disparities (a potential goal for health advocates), such as been done in Seattle in response to the COVID-19 pandemic's impact on low-income families [80]. The lower section of Fig. 1 (orange and purple) illustrates the potential responses by the beverage industry and consumers, which may be more immediate or lagged. This means that some components of complex interventions could or should be evaluated later in the timeline of the policy (and thus other contextual factors that may have evolved over that period will also need to be considered). Resultant micro or macro as well as time period specific outcomes of interest in evaluations of sweetened beverage taxes are show in Table 4, and the data sources to assess these outcomes, as well as their strengths and limitations, are further elaborated in the Supplementary file. 
Table 2 Examples of natural experiment methods used for evaluating sweetened beverage taxes

\begin{tabular}{llll}
\hline $\begin{array}{l}\text { Study design } \\
\text { (with statistical } \\
\text { method) }\end{array}$ & Advantages & Challenges & Example of evaluations \\
\hline $\begin{array}{llll}\text { Difference in } \\
\text { difference (using }\end{array}$ & $\begin{array}{l}\text { Reduces biases associated with time- } \\
\text { a control group) } \\
\text { interest. }\end{array}$ & $\begin{array}{l}\text { Requires that prior trends of the outcome } \\
\text { are similar between treatment and control } \\
\text { groups. Difficult to test if no prior data } \\
\text { available. }\end{array}$ & $\begin{array}{l}\text { Philadelphia (USA): the evaluation of } \\
\text { the tax was based on a difference in } \\
\text { difference analysis to estimate changes } \\
\text { in sales, using Baltimore as the } \\
\text { comparison city [30]. }\end{array}$
\end{tabular}

Difference in difference (with propensity score matching)

In absence of an experimental design PSM balances control and treatment comparison groups on basic characteristics using baseline data.
Interrupted time Creates a counterfactual based on pretax series (ITS) trends. Can be adapted to panel and crosssectional data.
ITS with synthetic controls
Creates a synthetic control based on a pool of potential comparison groups.
Unable to adjust for unobservable time variant variables.
No control group to adjust for all potential exposures to other policies or factors associated with the outcome of interest.
Requires countries with same data sets for the outcome and variables associated with the outcome prior to the intervention to create the synthetic control. Requires the magnitude and trends in the pretax period are not statistically different between treatment and synthetic control

No control group to adjust for all potential exposures to other policies or factors associated with the outcome of interest.
Philadelphia (USA): Created propensity score weights as inclusion in difference-in-difference models to account for differences in the composition of the four comparison groups and changes in their composition over time [58].

Mexico: Adapted ITS to a panel of urban households to estimate changes in household beverage purchases, using a fixed effects regression and adding household and contextual variables [29].

UK: Controlled ITS to look at sugar content, prices and beverage product availability from 2 years preannouncement to 1 year postimplementation [59]; Domestic turnover of UK soft drinks manufacturers pre-post announcement and implementation of the SDIL [60].

Mexico: Uses Mexico's Consumer Price Index price data collected from urban retail outlets across 46 cities to construct a synthetic control product whose pre-tax price most closely tracks that of the treatment product ('donor' products comprised of all untaxed nondurables that are neither potential substitutes for taxed drinks nor subject to the concurrent junk food tax) [61].

Chile: estimated changes in beverage prices and purchases associated with a tax policy modification in a panel of urban households adapting a ITS model with a correlated random effects model [62].

Denmark: Uses a regression

Requires cutoff to be exogenous (not linked to outcomes). Results more relevant for observations around cutoff (external validity can be difficult to establish) discontinuity (RD) approach to assess the pass-through of the tax changes and a within-household pre-post design to estimate changes in purchases of soft drinks [63].

\section{Practical challenges of complex evaluations}

There are of course real and practical challenges in evaluating sweetened beverage tax policies, including:

- Data availability - detailed data with valid measures for outcomes, sufficient sample sizes and time periods of interest may not exist.

- Time pressures - primary data collection may need to occur extremely quickly if there is a short time lag between policy passage and implementation, which may prevent researchers from collecting baseline (pre-implementation) measures of interest. This is more so the case if there are difficulties or delays in obtaining funding for primary data collection. Moreover, these tax policies are often heavily scrutinized and there is pressure to get results out quickly. Thus, it is wise to conduct routine quick assessments of all data possibilities and prioritise data that is available. This also means that researchers and policymakers should be in constant dialogue to ensure timelines are realistic. 
Table 3 Examples of simulation-based methods used for distal outcomes or comparing sweetened beverage tax designs

\begin{tabular}{llll}
\hline Simulation-based methods & Advantages & Challenges & Example of application \\
\hline Demand systems models such as & Accounts for simultaneous & Elasticity estimates may be sensitive & Connecticut \& Massachusetts, USA: \\
Almost Ideal Demand System & substitutions and complementarity & to how model used, beverage/food & Uses QUAIDS to estimate SSB \\
(AIDS); Quadratic Almost Ideal & across beverage \& food categories & categories included in the system & demand and tax among food \\
Demand System (QUAIDS), & to obtain own- and cross-price elas- & and sample sizes. & assistance participants [74]. \\
Rotterdam model, Exact Affine & ticities of demand as well as income & Beverage/food categories that are & Chile: Uses LAIDS to derive \\
Stone Index model (EASI) & or expenditure elasticities & not often purchased require more & beverage and food elasticities to \\
& If sample large enough, able to & complex econometric models. & infer what a tax might mean in \\
& disaggregate by income or other & Demand models are usually static & terms of changing consumption \\
& characteristic of interest to get & and does not account for habit & [75].
\end{tabular}

Demand- and supply-estimations for differentiated product markets using the Berry, Levinsohn and Pakes (BLP) model

\section{Able to account for beverage} market structure and shares of firms (manufacturers and/or retailers) and household socio-demographic characteristics to assess how much of the tax is passed onto consumers (strategic pricing) and hence what the resultant consumption changes accounting for substitutions, and new market share distribution might be.

If a tax is in place, possible to validate the structural demand and supply models.

Population-based microsimulation models (PSM) of which extended cost-effectiveness analyses (ECEA) are a subset

Computable general equilibrium (CGE) models of which inputoutput models or social accounting matrix are a part of.
Uses existing distribution of population characteristics collated from various data sources to construct a hypothetical population. Various policies or interventions and empirically informed effect sizes between dietary intake changes and health outcomes are applied as parameters to compare how outcomes would vary across these policies or interventions vis-à-vis the status-quo.

Able to assess macroeconomic/ economy-wide implications

(employment, sector-specific productivity, trade, gross domestic product) using representative agents (consumers, producers, government) and accounts for importexports for country
Requires detailed data on product attributes (e.g., brand, tax status) purchased by households.

Determination of inside- vs outsideoption may limit interpretation as the model assumes that the price of the outside option is unchanged. Only provides estimates of shortterm supply-side response to a tax as other strategies like changing portfolio mix and reformulations may follow.

Demand models are usually static and does not account for habit formation.

Assumes that diseases are independent of each other. Frequently due to data limitations, only key diet-disease relationships are included in models Unable to account for industry responses such as reformulations or changes in marketing. Need to define time horizon given population cohort and assume discount rates.

Validation of assumption and methods needed but often difficult.

Assumes that demand elasticities are fixed and independent of policy Requires additional parameters from demand systems model estimates, market share changes, PSM and cost-effectiveness estimates and thus only possible later in the lifecycle of the evaluation.
France: Comparing firms' strategic price responses to an ad valorem vs excise taxes on sweetened

beverages [73].

Mexico: Comparing changes in volume of and sugar from taxed vs untaxed beverages purchased as well as tax revenues generated under SSB taxes based on sugardensity vs volume [76].
USA: Applies the CHOICES model to estimate cost-effectiveness of a 1 cent/ounce tax on SSBs [70]. Australia: Multi-state lifetable model of a hypothetical 20\% SSB tax on the monetized productivity of

adults 20y or older [77].

South Africa: Estimates changes in Type 2 Diabetes-related deaths for different income groups and the resultant burden to individual and public payers due to a $20 \%$ SSB tax [78].

Guatemala: Considers the whole value chain, from the production of sugar to the different productive sectors that use sugar and the final consumer to evaluate the overall effects various SSB tax policies [79]. framing $[81,82]$. In such circumstances, arguments are often made about the problems of the 'nanny state', job losses and regressivity of a tax. Besides generating evidence to address these concerns (e.g., via data analyses, evidence synthesis and modelling), researchers can readily counter such arguments in discussing their findings, thus presenting an alternative framing based on the science [83].

- Obtaining conflict-free funding - it is important that objective and independent evaluations of sweetened beverages taxes take place, without interference from those with vested interests [82, 84-87]. Gaining support for such evaluations in the relevant setting may be difficult, but support may be available from promoted and supported by industry through media 
Table 4 Outcomes or measures of interest by stakeholder

\begin{tabular}{|c|c|c|c|c|c|}
\hline Stakeholder & Consum & & Beverage industry & Government & Health Advocates \\
\hline $\begin{array}{l}\text { Time } \\
\text { periods }\end{array}$ & $\begin{array}{l}\text { Pre-tax and }<5 \text { years post-tax } \\
\text { implementation }\end{array}$ & $\begin{array}{l}\text { Pre-tax and }>5 \text { years } \\
\text { post-tax implementation }\end{array}$ & $\begin{array}{l}\text { Pre-tax and post-tax } \\
\text { implementation }\end{array}$ & Post-tax implementation & $\begin{array}{l}\text { Pre- and post-tax } \\
\text { implementation }\end{array}$ \\
\hline Micro & $\begin{array}{l}\text { - Awareness, understanding, } \\
\text { and support of tax } \\
\text { - Knowledge of health } \\
\text { implications unhealthy } \\
\text { beverage consumption } \\
\text { - Purchases or intake of taxed } \\
\text { and untaxed beverages in } \\
\text { terms of volume, sugar and } \\
\text { calories } \\
\text { - Total sugar in diet and } \\
\text { compensatory consumption } \\
\text { of other foods or beverages } \\
\text { - Select biomarkers (e.g., } \\
\text { HbA1c) }\end{array}$ & $\begin{array}{l}\text { Continue earlier } \\
\text { measures to assess } \\
\text { sustainability of } \\
\text { consumer changes }\end{array}$ & $\begin{array}{l}\text { - Marketing practices } \\
\text { (mix of product, price, } \\
\text { placement and } \\
\text { promotion). } \\
\text { o Price changes relative } \\
\text { to liable tax (degree of } \\
\text { pass-through) } \\
\text { o Sugar content of } \\
\text { beverages } \\
\text { o Product offerings } \\
\text { across beverage types, } \\
\text { formats, markets, } \\
\text { regions } \\
\text { o Types of signage or } \\
\text { messaging on receipts } \\
\text { about tax, by store type } \\
\text { - Store revenue overall } \\
\text { and for beverages } \\
\text { - Costs for research \& } \\
\text { development, new } \\
\text { packaging }\end{array}$ & $\begin{array}{l}\text { Implementation, } \\
\text { administration, } \\
\text { collection and } \\
\text { enforcement of tax: } \\
\text { - Guidance to } \\
\text { stakeholders } \\
\text { - Mechanisms for } \\
\text { collection and } \\
\text { enforcement } \\
\text { - Communication of } \\
\text { goal of tax to the } \\
\text { public } \\
\text { - Costs of above }\end{array}$ & $\begin{array}{l}\text { - Programs supported by } \\
\text { tax revenue allocation } \\
\text { and impacts on } \\
\text { community } \\
\text { - Composition and } \\
\text { coherence of advocacy } \\
\text { coalition }\end{array}$ \\
\hline Macro & $\begin{array}{l}\text { - Affordability of taxed vs } \\
\text { untaxed beverages } \\
\text { - Modelled simulations of } \\
\text { longer-term health and } \\
\text { healthcare cost outcomes }\end{array}$ & $\begin{array}{l}\text { Empirical measures of } \\
\text { incidence \& prevalence } \\
\text { of: } \\
\text { - Type } 2 \text { diabetes } \\
\text { - Dental caries }\end{array}$ & $\begin{array}{l}\text { - Employment by/ } \\
\text { across industries } \\
\text { - Market share of key } \\
\text { beverage types } \\
\text { - Market value (stock } \\
\text { prices) of companies } \\
\text { - Expenditures on } \\
\text { lobbying and legal } \\
\text { action to fight or } \\
\text { repeal tax }\end{array}$ & $\begin{array}{l}\text { - Tax revenue collected } \\
\text { - Tax revenue allocated } \\
\text { over time and by } \\
\text { purpose } \\
\text { - Political acceptability } \\
\text { of wider policy } \\
\text { measures and } \\
\text { government's role }\end{array}$ & $\begin{array}{l}\text { - Expenditures on } \\
\text { campaigning and legal } \\
\text { action to support tax } \\
\text { - Perceptions and } \\
\text { attitudes on the role of } \\
\text { advocacy and civil } \\
\text { society }\end{array}$ \\
\hline
\end{tabular}

government sources, private philanthropies or foundations, global research funds or a mixture of these sources. Care should be taken to consider all potential forms of interests to establish ways to mitigate or at the very least, disclose them $[86,88,89]$.

- Media attacks - vested interests (e.g., political thinktanks, industry foundations) and elements of the public media are often aligned with government or opposition views. Either side may attempt to discredit evaluations of sweetened beverage taxes to which they are ideologically opposed through media articles [90]. As indicated above, such attacks can be countered, but sometimes are meant to distract from the work at hand, and may be best ignored by researchers and/or countered by other stakeholders (e.g., advocacy).

- Communication of evaluation findings beyond academia - the complex methodologies of rigorous research can create confusion if not communicated well. However, while access to policymakers and other stakeholders can be difficult, it is valuable for researchers to communicate their findings to a wide audience beyond academia, using multiple channels to maximise impact of their research.
Given these challenges, researchers, policymakers and funders should be mindful and realistic in the scope of evaluations, keeping the following questions in mind to guide decisions:

- How unique is the tax policy design or context?

- What research capacity/know-how exists, given the timeframe, to execute the work?

- What are the existing knowledge gaps and critical uncertainties that your research might uniquely be able to address?

- How can your evaluation contribute more widely to generalizable causal inference regarding sweetened beverage taxes?

- What is the anticipated time-horizon by which any meaningful changes in outcomes should be expected? Will there be resources to do conduct a study over this time-horizon?

\section{Making sense of the findings}

Once new evidence has been generated on the implications of the sweetened beverage tax for outcomes of interest, it is then useful to revisit the prior programme 
theory, conceptual map or logic model. This allows evaluators to:

- Interpret the findings across multiple outcome measures in relation to a given context, theory of change or expected results (e.g., the Obesity Prevention Evidence Assessment Framework [37])

- Explain unexpected results

- Synthesize findings from multiple methods (including using formal methods, such as triangulation protocol [91], pattern matching [92] or process tracing [93])

- Integrate findings from multiple similar analyses using integration methods (e.g., meta-analyses of multiple interrupted time-series analyses $[23,53$, 94])

Returning to stakeholders to review the findings and to make sense of any counterintuitive findings by identifying nuances that the data might not have captured will be important as well as informative for future evaluation efforts [95].

All stakeholders, including researchers and funders, should be fully cognisant of study limitations given that no single source of data, method or evaluation will be perfect or necessarily produce generalizable findings. Even consistent findings across multiple methods for a said location or policy do not necessarily mean that that same policy implemented elsewhere will produce similar results. There are lessons learned from elsewhere to inform policy development, but local context also matters and needs to be taken into account. This is particularly true when taking a systems approach to understand how stakeholders interact or respond $[95,96]$.

\section{Conclusions}

Careful evaluation of public health policies can generate evidence to support the refinement of existing policies and inform the development of new policies elsewhere. The guidance provided here builds on lessons learned to date from a range of evaluations of sweetened beverage tax policies. We anticipate that it will help in planning future evaluations of sweetened beverage taxes and, in addition, be applicable to the evaluation of other food policies, like food labelling or marketing regulations. We hope that this article will help researchers and policymakers consider how to prioritise evaluation questions and choose appropriate study designs and methods, given potentially limited data, resources and time, and hence the practical trade-offs that they may need to decide among within each context. We recommend adopting a systems perspective, incorporating insights from multiple disciplines and stakeholders, developing a communications plan, and being creative in identifying a mixture of data sources and applying diverse methods informed by systems thinking, involving a range of relevant stakeholders at each step of the evaluation process.

\begin{abstract}
Abbreviations
AIDS: Almost Ideal Demand System; GST: Goods and Services Tax; HS: Harmonised System; ITS: Interrupted Time Series; NCD: NonCommunicable Diseases; PSM: Population-based Simulation Models; QUAIDS: Quadratic Almost Ideal Demand System; RD: Regression Discontinuity; SDIL: United Kingdom's Soft Drink Industry Levy; SSB: Sugar Sweetened Beverage; VAT: Value- Added Tax
\end{abstract}

\section{Supplementary Information}

The online version contains supplementary material available at https://doi. org/10.1186/s12889-021-11984-2.

Additional file 1.

Acknowledgements

We thank Ms. Emily Busey for graphics assistance and support.

\section{Authors' contributions}

SWN led on the paper conceptualization, drafting of the manuscript, critical revisions and coordination of the paper on a whole. MAC contributed to the drafting and review of the paper. MW contributed to the paper

conceptualization, drafting and review. All authors provided final approval of the manuscript for submission.

\section{Funding}

SWN's position is partly funded by the University of North Carolina at Chapel Hill and partly funded by research grants from the US National Institutes of Health (DK098072, DK056350, P2C HD050924), Arnold Ventures and Bloomberg Philanthropies. MAC's position is funded by the Instituto Nacional de Salud Pública in Mexico, and complemented with research grants from Bloomberg Philanthropies, US National Institutes of Health, National Council on Science and Technology and Bill and Melinda Gates Foundation. MW holds a tenured post funded by the University of Cambridge. He holds research programme and project funding from The National Institute of Health Research (NIHR) (grant number 16/130/01) to evaluate the UK Soft Drinks Industry Levy. MW also receives other grant funding from NIHR and his research programme is supported by funding from the Medical Research Council (MRC) via the MRC Epidemiology Unit, University of Cambridge [grant number MC/UU/12015/6] and Centre for Diet and Activity Research (CEDAR), a UK Clinical Research Collaboration (UKCRC) Public Health Research Centre of Excellence. Funding for CEDAR from the British Heart Foundation, Cancer Research UK, Economic and Social Research Council, Medical Research Council, the National Institute for Health Research [grant numbers ES/G007462/1 and MR/K023187/1], and the Wellcome Trust [grant number 087636/Z/08/Z], under the auspices of the UK Clinical Research Collaboration is gratefully acknowledged. Funders had no role in the writing of this paper.

\section{Availability of data and materials}

Data sharing is not applicable to this article as no datasets were generated or analysed during the current study.

\section{Declarations}

Ethics approval and consent to participate

Not applicable as this paper does not involve human subjects.

Consent for publication

Not applicable.

Competing interests

The authors declare that they have no competing interests. 


\section{Author details}

${ }^{1}$ Carolina Population Center, University of North Carolina at Chapel Hill, CB \#8120, 137 East Franklin Street, Chapel Hill, NC 27516, USA. ${ }^{2}$ Department of Nutrition, Gillings School of Global Public Health, University of North Carolina at Chapel Hill, CB\#7461, UNC-Chapel Hill, Chapel Hill, NC 27599-7461, USA. ${ }^{3}$ Center for Health Systems Research, Instituto Nacional de Salud Pública, Universidad No 655 Colonia Santa María Ahuacatitlán, Cerrada Los Pinos y Caminera, CP, 62100 Cuernavaca, Morelos, Mexico. ${ }^{4}$ Centre for Diet and Activity Research, MRC Epidemiology Unit, University of Cambridge, Cambridge, UK.

\section{Received: 18 February 2021 Accepted: 12 October 2021} Published online: 26 October 2021

\section{References}

1. Malik VS, Popkin BM, Bray GA, Despres J-P, Hu FB. Sugar-Sweetened Beverages, Obesity, Type 2 Diabetes Mellitus, and Cardiovascular Disease Risk. Circulation. 2010;121(11):1356-64.

2. Basu S, McKee M, Galea G, Stuckler D. Relationship of soft drink consumption to global overweight, obesity, and diabetes: a cross-National Analysis of 75 countries. Am J Public Health. 2013;103(11):2071-7. https:// doi.org/10.2105/AJPH.2012.300974.

3. Kim Y, Je Y. Prospective association of sugar-sweetened and artificially sweetened beverage intake with risk of hypertension. Arch Cardiovasc Dis 2016;109(4):242-53. https://doi.org/10.1016/j.acvd.2015.10.005.

4. Chazelas E, Srour B, Desmetz E, Kesse-Guyot E, Julia C, Deschamps V, et al. Sugary drink consumption and risk of cancer: results from NutriNet-Santé prospective cohort. BMJ. 2019;366:I2408. https://doi.org/10.1136/bmj.I2408.

5. Hodge AM, Bassett JK, Milne RL, English DR, Giles GG. Consumption of sugar-sweetened and artificially sweetened soft drinks and risk of obesityrelated cancers. Public Health Nutr. 2018;21(9):1618-26. https://doi.org/10.1 017/S1368980017002555

6. Mullee A, Romaguera D, Pearson-Stuttard J, Viallon V, Stepien M, Freisling H, et al. Association between soft drink consumption and mortality in 10 European CountriesAssociation between soft drink consumption and mortality in EuropeAssociation between soft drink consumption and mortality in Europe. JAMA Intern Med. 2019;180(2):336. https://doi.org/10.1 001/jamainternmed.2019.6127.

7. Popkin BM, Hawkes C. Sweetening of the global diet, particularly beverages: patterns, trends, and policy responses. Lancet Diabetes Endocrinol. 2016; 4(2):174-86. https://doi.org/10.1016/S2213-8587(15)00419-2.

8. Singh GM, Micha R, Khatibzadeh S, Shi P, Lim S, Andrews KG, et al. Global, regional, and National Consumption of sugar-sweetened beverages, fruit juices, and Milk: a systematic assessment of beverage intake in 187 countries. PLoS One. 2015;10(8):e0124845. https://doi.org/10.1371/journal. pone.0124845

9. Bleich SN, Vercammen KA, Koma JW, Li Z. Trends in beverage consumption among children and adults, 2003-2014. Obesity (Silver Spring). 2018;26(2): 432-41. https://doi.org/10.1002/oby.22056.

10. Marten R, Kadandale S, Butler J, Aguayo VM, Axelrod S, Banatvala N, et al. Sugar, tobacco, and alcohol taxes to achieve the SDGs. Lancet. 2018; 391(10138):2400-1. https://doi.org/10.1016/S0140-6736(18)31219-4.

11. Bertram M, Banatvala N, Kulikov A, Belausteguigoitia I, Sandoval R, Hennis A, et al. Using economic evidence to support policy decisions to fund interventions for non-communicable diseases. BMJ. 2019;365:11648. https:// doi.org/10.1136/bmj.l1648.

12. World Health Organization. Fiscal policies for diet and prevention of noncommuicable diseases: technical meeting report. Geneva: Data WLC-i-P; 2016.

13. Summers LH. Taxes for health: evidence clears the air. Lancet. 2018; 391(10134):1974-6. https://doi.org/10.1016/S0140-6736(18)30629-9.

14. Sassi F, Belloni A, Mirelman AJ, Suhrcke M, Thomas A, Salti N, et al. Equity impacts of price policies to promote healthy behaviours. Lancet. 2018; 391(10134):2059-70. https://doi.org/10.1016/S0140-6736(18)30531-2.

15. World Health Organization. Fiscal policies for diet and prevention of noncommunicable diseases. In: Technical meeting report. Geneva: World Health Organization; 2016.

16. Chaloupka FJ, Powell LM, Warner KE. The use of excise taxes to reduce tobacco, alcohol, and sugary beverage consumption. Annu Rev Public Health. 2019:40(1):187-201. https://doi.org/10.1146/annurev-publhealth-04 0218-043816.
17. Cabrera Escobar MA, Veerman JL, Tollman SM, Bertram MY, Hofman KJ. Evidence that a tax on sugar sweetened beverages reduces the obesity rate: a meta-analysis. BMC Public Health. 2013;13(1):1072. https://doi.org/1 0.1186/1471-2458-13-1072.

18. Backholer K, Sarink D, Beauchamp A, Keating C, Loh V, Ball K, et al. The impact of a tax on sugar-sweetened beverages according to socioeconomic position: a systematic review of the evidence. Public Health Nutr. 2016;19(17):3070-84. https://doi.org/10.1017/S136898001600104X.

19. Nakhimovsky SS, Feigl AB, Avila C, O'Sullivan G, Macgregor-Skinner E, Spranca M. Taxes on sugar-sweetened beverages to reduce overweight and obesity in middle-income countries: a systematic review. PLoS One. 2016; 11(9):e0163358. https://doi.org/10.1371/journal.pone.0163358.

20. Alagiyawanna A, Townsend N, Mytton O, Scarborough P, Roberts N, Rayner M. Studying the consumption and health outcomes of fiscal interventions (taxes and subsidies) on food and beverages in countries of different income classifications; a systematic review. BMC Public Health. 2015;15(1): 887. https://doi.org/10.1186/s12889-015-2201-8.

21. Thow AM, Jan S, Leeder S, Swindurn B. The effect of fiscal policy on diet, obesity and chronic disease: a systematic review. Bull World Health Organ. 2010;88(8):609-14. https://doi.org/10.2471/BLT.09.070987.

22. NOURISHING Database [https://policydatabase.wcrf.org/level_one?page= nourishing-level-one].

23. Teng AM, Jones AC, Mizdrak A, Signal L, Genç M, Wilson N. Impact of sugarsweetened beverage taxes on purchases and dietary intake: systematic review and meta-analysis. Obes Rev. 2019;20(9):1187-204. https://doi.org/1 $0.1111 /$ obr.12868

24. Cawley J, Thow AM, Wen K, Frisvold D. The economics of taxes on sugarsweetened beverages: a review of the effects on prices, sales, cross-border shopping, and consumption. Annu Rev Nutr. 2019;39(1):317-38. https://doi. org/10.1146/annurev-nutr-082018-124603.

25. Hawkes C, Alderman H, Chaloupka F, Harris J, Kumanyika S, Smed S, et al. Principles behind evaluations of national food and beverage taxes and other regulatory efforts. Obes Rev. 2017;18(11):1374-5. https://doi.org/1 $0.1111 / \mathrm{obr} .12594$.

26. Map and chart the movement [http://www.healthyfoodamerica.org/map].

27. Alvarado M, Unwin N, Sharp SJ, Hambleton I, Murphy MM, Samuels TA, et al. Assessing the impact of the Barbados sugar-sweetened beverage tax on beverage sales: an observational study. Int J Behav Nutr Phys Act. 2019; 16(1):13. https://doi.org/10.1186/s12966-019-0776-7.

28. Adhana D, Raghuvanshi RR: Goods and Service Tax (GST): A Game Changer for Indian Economy. Proceedings of National Conference on 'Contemporary Issues in Business Excellence in the Era of Digitalization' (CIBEED -2019). Available at SSRN: https://ssrn.com/abstract=3452717 or https://doi.org/1 0.2139/ssrn.3452717 2019.

29. Colchero MA, Rivera-Dommarco J, Popkin BM, Ng SW. In Mexico, evidence of sustained consumer response two years after implementing a sugarsweetened beverage tax. Health Aff. 2017;36(3):564-71. https://doi.org/10.13 77/hlthaff.2016.1231

30. Roberto CA, Lawman HG, LeVasseur MT, Mitra N, Peterhans A, Herring B, et al. Association of a Beverage tax on sugar-sweetened and artificially sweetened beverages with changes in beverage prices and sales at chain retailers in a large urban setting. JAMA. 2019;321(18):1799-810. https://doi. org/10.1001/jama.2019.4249.

31. Buckton $\mathrm{CH}$, Fergie $\mathrm{G}$, Leifeld $\mathrm{P}$, Hilton $\mathrm{S}$. A discourse network analysis of UK newspaper coverage of the "sugar tax" debate before and after the announcement of the soft drinks Industry levy. BMC Public Health. 2019; 19(1):490. https://doi.org/10.1186/s12889-019-6799-9.

32. Stacey N, Mudara C, Ng SW, van Walbeek C, Hofman K, Edoka I. Sugarbased beverage taxes and beverage prices: evidence from South Africa's health promotion levy. Soc Sci Med. 2019;238:112465. https://doi.org/10.101 6/j.socscimed.2019.112465.

33. Stacey N, Edoka I, Hofman K, Swart EC, Popkin B, Ng SW. Changes in beverage purchases following the announcement and implementation of South Africa's health promotion levy: an observational study. Lancet Planetary Health. 2021; 5(4):e200-8. https://doi.org/10.1016/S2542-5196(20)30304-1.

34. Onagan FCC, Ho BLC, Chua KKT. Development of a sweetened beverage tax, Philippines. Bull World Health Organ. 2019;97(2):154-9. https://doi.org/1 0.2471/BLT.18.220459.

35. Bandy LK, Scarborough P, Harrington RA, Rayner M, Jebb SA. Reductions in sugar sales from soft drinks in the UK from 2015 to 2018. BMC Med. 2020; 18(1):20. https://doi.org/10.1186/s12916-019-1477-4. 
36. Leicester A, Levell P, Rasul I. Tax and benefit policy: insights from behavioural economics. In: IFS Commentary C125. The Institute for Fiscal Studies; 2012.

37. Sacks G, Kwon J, Ananthapavan J. The application of an evidence framework for obesity prevention at the population-level. Curr Obes Rep. 2020:9(2):150-8. https://doi.org/10.1007/s13679-020-00376-z.

38. Ogilvie D, Cummins S, Petticrew M, White M, Jones A, Wheeler K. Assessing the Evaluability of complex public health interventions: five questions for researchers, funders, and policymakers. Milbank Q. 2011;89(2):206-25. https://doi.org/10.1111/j.1468-0009.2011.00626.x.

39. Mytton OT, Eyles $\mathrm{H}$, Ogilvie D. Evaluating the health impacts of food and beverage taxes. Curr Obes Rep. 2014;3(4):432-9. https://doi.org/10.1007/s13 679-014-0123-x.

40. Hawkes C, Smith TG, Jewell J, Wardle J, Hammond RA, Friel S, et al. Smart food policies for obesity prevention. Lancet. 2015;385(9985):2410-21. https://doi.org/10.1016/S0140-6736(14)61745-1.

41. Finegood DT, Merth TDN, Rutter H. Implications of the foresight obesity system map for solutions to childhood obesity. Obesity. 2010;18(S1):S13-6.

42. McGill E, Er V, Penney T, Egan M, White M, Meier P, et al. Evaluation of public health interventions from a complex systems perspective: A research methods review. Soc Sci Med. 2021;272:113697. https://doi.org/10.1016/j. socscimed.2021.113697.

43. UCSF Industry Documents Library: Industry Documents Library. In. https:// www.industrydocuments.ucsf.edu: University of California San Francisco; online.

44. National Insitute of Health Research UK. Evaluation of the health impacts of the UK Treasury Soft Drinks Industry Levy (SDIL). In: PHR - 16/130/01. July 2017; 2017.

45. Chriqui JF, Sansone CN, Powell LM. The sweetened beverage tax in Cook County, Illinois: lessons from a failed effort. Am J Public Health. 2020;110(7): 1009-16. https://doi.org/10.2105/AJPH.2020.305640.

46. Pell D, Penney T, Hammond D, Vanderlee L, White M, Adams J. Support for, and perceived effectiveness of, the UK soft drinks industry levy among UK adults: cross-sectional analysis of the international food policy study. BMJ Open. 2019;9(3):e026698. https://doi.org/10.1136/bmjopen-2018-026698.

47. Niederdeppe J, Gollust SE, Jarlenski MP, Nathanson AM, Barry CL. News coverage of sugar-sweetened beverage taxes: pro- and Antitax arguments in public discourse. Am J Public Health. 2013;103(6):e92-8. https://doi.org/1 0.2105/AJPH.2012.301023.

48. Madsen KA. Sugar-sweetened beverage taxes: a political Battle. Am J Public Health. 2020;110(7):929-30. https://doi.org/10.2105/AJPH.2020.305714.

49. Jenkin GL, Signal L, Thomson G. Framing obesity: the framing contest between industry and public health at the New Zealand inquiry into obesity. Obes Rev. 2011;12(12):1022-30. https://doi.org/10.1111/j.1467789X.2011.00918.X

50. Moore G, Audrey S, Barker M, Bond L, Bonell C, Cooper C, et al. Process evaluation in complex public health intervention studies: the need for guidance. J Epidemiol Community Health. 2014;68(2):101-2. https://doi. org/10.1136/jech-2013-202869.

51. Falbe J, Grummon AH, Rojas N, Ryan-Ibarra S, Silver LD, Madsen KA. Implementation of the first US sugar-sweetened beverage tax in Berkeley, CA, 2015-2019. Am J Public Health. 2020, In press;110(9):-1437. https://doi. org/10.2105/AJPH.2020.305795.

52. Ogilvie D, Adams J, Bauman A, Gregg EW, Panter J, Siegel KR, et al. Using natural experimental studies to guide public health action: turning the evidence-based medicine paradigm on its head. J Epidemiol Community Health. 2020;74(2):203-8. https://doi.org/10.1136/jech-2019-213085.

53. Mounsey $S$, Veerman $L$, Jan $S$, Thow AM. The macroeconomic impacts of diet-related fiscal policy for NCD prevention: a systematic review. Econ Hum Biol. 2020;37:100854. https://doi.org/10.1016/j.ehb.2020.100854.

54. Craig P, Katikireddi SV, Leyland A, Popham F. Natural experiments: an overview of methods, approaches, and contributions to public health intervention research. Annu Rev Public Health. 2017;38(1):39-56. https://doi. org/10.1146/annurev-publhealth-031816-044327.

55. Basu S, Meghani A, Siddiqi A. Evaluating the health impact of large-scale public policy changes: classical and novel approaches. Annu Rev Public Health. 2017;38(1):351-70. https://doi.org/10.1146/annurev-publhealth-03181 6-044208.

56. Leatherdale ST. Natural experiment methodology for research: a review of how different methods can support real-world research. Int J Soc Res Methodol. 2019;22(1):19-35. https://doi.org/10.1080/13645579.2018.1488449.
57. Snell A, Reeves A, Rieger M, Galea G, Mauer-Stender K, Mikkelsen B, et al WHO Regional Office for Europe's Natural Experiment Studies Project: an introduction to the series. Eur J Pub Health. 2018;28(suppl_2):1-3.

58. Zhong Y, Auchincloss AH, Lee BK, Kanter GP. The short-term impacts of the Philadelphia beverage tax on beverage consumption. Am J Prev Med. 2018; 55(1):26-34. https://doi.org/10.1016/j.amepre.2018.02.017.

59. Scarborough P, Adhikari V, Harrington RA, Elhussein A, Briggs A, Rayner M, et al. Impact of the announcement and implementation of the UK soft drinks Industry levy on sugar content, price, product size and number of available soft drinks in the UK, 2015-19: a controlled interrupted time series analysis. PLoS Med. 2020;17(2):e1003025. https://doi.org/10.1371/journal. pmed. 1003025.

60. Law C, Cornelsen L, Adams J, Pell D, Rutter H, White M, et al. The impact of UK soft drinks industry levy on manufacturers' domestic turnover. Econ Hum Biol. 2020;37:100866. https://doi.org/10.1016/j.ehb.2020.100866.

61. Grogger J. Soda taxes and the prices of sodas and other drinks: evidence from Mexico. Am J Agric Econ. 2017;99(2):481-98. https://doi.org/10.1093/a jae/aax024.

62. Caro JC, Corvalán C, Reyes M, Silva A, Popkin B, Taillie LS. Chile's 2014 sugarsweetened beverage tax and changes in prices and purchases of sugarsweetened beverages: an observational study in an urban environment. PLoS Med. 2018;15(7):e1002597. https://doi.org/10.1371/journal.pmed.1002597.

63. Schmacker R, Smed S. Do prices and purchases respond similarly to soft drink tax increases and cuts? Econ Hum Biol. 2020;37:100864. https://doi. org/10.1016/j.ehb.2020.100864.

64. Eyles H, Ni Mhurchu C, Nghiem N, Blakely T. Food pricing strategies, population diets, and non-communicable disease: a systematic review of simulation studies. PLoS Med. 2012;9(12):e1001353. https://doi.org/10.1371/ journal.pmed.1001353.

65. Powell LM, Wada R, Persky JJ, Chaloupka FJ. Employment impact of sugarsweetened beverage taxes. Am J Public Health. 2014;104(4):672-7. https:// doi.org/10.2105/AJPH.2013.301630.

66. Caro JC, Ng SW, Bonilla R, Tovar J, Popkin BM. Sugary drinks taxation, projected consumption and fiscal revenues in Colombia: evidence from a QUAIDS model. PLoS One. 2017;12(12):e0189026. https://doi.org/10.1371/ journal.pone.0189026.

67. Manyema M, Veerman $J$, Chola L, Tugendhaft A, Labadarios D, Hofman K Decreasing the burden of type 2 diabetes in South Africa: the impact of taxing sugar-sweetened beverages. PLoS One. 2015;10(11):e0143050. https:// doi.org/10.1371/journal.pone.0143050.

68. Briggs ADM, Mytton OT, Kehlbacher A, Tiffin R, Rayner M, Scarborough P. Overall and income specific effect on prevalence of overweight and obesity of $20 \%$ sugar sweetened drink tax in UK: econometric and comparative risk assessment modelling study. BMJ. 2013;347(oct31 4):f6189. https://doi.org/1 $0.1136 / \mathrm{bmj} . f 6189$.

69. Barrientos-Gutierrez T, Zepeda-Tello R, Rodrigues ER, Colchero-Aragonés A, Rojas-Martínez R, Lazcano-Ponce E, et al. Expected population weight and diabetes impact of the 1-peso-per-litre tax to sugar sweetened beverages in Mexico. PLoS One. 2017;12(5):e0176336. https://doi.org/10.1371/journal. pone.0176336

70. Long MW, Gortmaker SL, Ward ZJ, Resch SC, Moodie ML, Sacks G, et al. Cost effectiveness of a sugar-sweetened beverage excise tax in the U.S. Am J Prev Med. 2015;49(1):112-23. https://doi.org/10.1016/j.amepre.2015.03.004.

71. Balbinotto G, Cardoso L. Measuring the economic impact of Ssb taxes in Brazil: an input-output analysis. Value Health. 2016;19(3):A101. https://doi. org/10.1016/j.jval.2016.03.1728.

72. Salgado-Hernandez JC, Ng SW, McManus B, Trogdon J. Simulating international tax designs on sugar-sweetened beverages in Mexico. In: Simulating alternative tax policies for sugar-sweetened beverages: consumer and producer outcomes in Mexico. In. Edited by Hill U-C; 2020.

73. Bonnet $C$, Réquillart $V$. Tax incidence with strategic firms in the soft drink market. J Public Econ. 2013;106:77-88. https://doi.org/10.1016/j.jpubeco.2 013.06.010.

74. Jithitikulchai T, Andreyeva T. Sugar-sweetened beverage demand and tax simulation for Federal Food Assistance Participants: a case of two New England states. Appl Health Econ Health Policy. 2018;16(4):549-58. https:// doi.org/10.1007/s40258-018-0399-1.

75. Guerrero-López CM, Unar-Munguía M, Colchero MA. Price elasticity of the demand for soft drinks, other sugar-sweetened beverages and energy dense food in Chile. BMC Public Health. 2017;17(1):180. https://doi.org/10.11 86/s12889-017-4098-x 
76. Salgado Hernández JC, Ng SW. Simulating international tax designs on sugar-sweetened beverages in Mexico. PLoS One. 2021;16(8):e0253748. https://doi.org/10.1371/journal.pone.0253748.

77. Nomaguchi T, Cunich M, Zapata-Diomedi B, Veerman JL. The impact on productivity of a hypothetical tax on sugar-sweetened beverages. Health Policy. 2017:121(6):715-25. https://doi.org/10.1016/j.healthpol.2017.04.001.

78. Saxena A, Stacey N, Puech PDR, Mudara C, Hofman K, Verguet S. The distributional impact of taxing sugar-sweetened beverages: findings from an extended cost-effectiveness analysis in South Africa. BMJ Glob Health 2019;4(4):e001317. https://doi.org/10.1136/bmjgh-2018-001317.

79. Piñeiro V, Bonilla ED, Paz F, Allen S. Sugar Taxes: An Economy-Wide Assessment The Case of Guatemala. In: IFPRI (International Food Policy Research Institute); 2019.

80. Scruggs $G$. Seattle turns soda tax revenue into emergency grocery vouchers during pandemic. Next City; 2020.

81. Tangcharoensathien V, Chandrasiri O, Kunpeuk W, Markchang K, Pangkariya N. Addressing NCDs: challenges from Industry market promotion and interferences. Int J Health Policy Manag. 2019;8(5):256-60. https://doi.org/1 0.15171/ijhpm.2019.02.

82. Collin J, Hill SE, Kandlik Eltanani M, Plotnikova E, Ralston R, Smith KE. Can public health reconcile profits and pandemics? An analysis of attitudes to commercial sector engagement in health policy and research. PLoS One. 2017;12(9):e0182612. https://doi.org/10.1371/journal.pone.0182612.

83. Carter SM, Entwistle VA, Little M. Relational conceptions of paternalism: a way to rebut nanny-state accusations and evaluate public health interventions. Public Health. 2015;129(8):1021-9. https://doi.org/10.1016/j. puhe.2015.03.007.

84. Nestle M. Food Industry funding of nutrition research: the relevance of history for current debates. JAMA Intern Med. 2016;176(11):1685-6. https:// doi.org/10.1001/jamainternmed.2016.5400.

85. Nestle M. Corporate funding of food and nutrition research: science or marketing? JAMA Intern Med. 2016;176(1):13-4. https://doi.org/10.1001/jama internmed.2015.6667.

86. Cullerton K, Adams J, Francis O, Forouhi N, White M. Building consensus on interactions between population health researchers and the food industry: two-stage, online, international Delphi study and stakeholder survey. PLoS One. 2019;14(8):e0221250. https://doi.org/10.1371/journal.pone.0221250.

87. Kearns CE, Schmidt LA, Glantz SA. Sugar Industry and coronary heart disease research: a historical analysis of internal Industry Documents. JAMA Intern Med. 2016;176(11):1680-5. https://doi.org/10.1001/jamainternmed.2016.5394.

88. loannidis JPA, Trepanowski JF. Disclosures in nutrition research: why it is different. JAMA. 2018;319(6):547-8. https://doi.org/10.1001/jama.2017.18571.

89. Cullerton K, Adams J, Forouhi N, Francis O, White M. What principles should guide interactions between population health researchers and the food industry? Systematic scoping review of peer-reviewed and grey literature. Obes Rev. 2019;20(8):1073-84. https://doi.org/10.1111/obr.12851.

90. Donaldson EA, Cohen JE, Truant PL, Rutkow L, Kanarek NF, Barry CL. News media framing of New York City's sugar-sweetened beverage portion-size cap. Am J Public Health. 2015;105(11):2202-9. https://doi.org/10.2105/AJPH.2 015.302673 .

91. Tonkin-Crine S, Anthierens S, Hood K, Yardley L, Cals JWL, Francis NA, et al. Discrepancies between qualitative and quantitative evaluation of randomised controlled trial results: achieving clarity through mixed methods triangulation. Implement Sci. 2016;11(1):66. https://doi.org/10.1186/ s13012-016-0436-0.

92. Trochim WMK. Pattern matching, validity, and conceptualization in program evaluation. Eval Rev. 1985;9(5):575-604. https://doi.org/10.1177/0193841 X8500900503.

93. Beach D. Process-tracing methods in social science: Oxford University Press; 2017. https://doi.org/10.1093/acrefore/9780190228637.013.176.

94. Ejlerskov KT, Sharp SJ, Stead M, Adamson AJ, White M, Adams J. Supermarket policies on less-healthy food at checkouts: natural experimental evaluation using interrupted time series analyses of purchases. PLoS Med. 2018;15(12):e1002712. https://doi.org/10.1371/journal.pmed.1002 712.

95. Rutter H, Savona N, Glonti K, Bibby J, Cummins S, Finegood DT, et al. The need for a complex systems model of evidence for public health. Lancet. 2017;390(10112):2602-4. https://doi.org/10.1016/S0140-6736(17)31267-9.

96. Craig P DRE, Frohlich $\mathrm{KL}$, et al. on behalf of the Canadian Institutes of Health Research (CIHR)-National Institute for Health Research (NIHR) Context Guidance Authors Group (listed alphabetically),: Taking account of context in population health intervention research: guidance for producers, users and funders of research. In., vol. https://www.ncbi.nlm.nih.gov/books/ NBK498645/?report=classic. Southampton (UK): NIHR Journals Library; 2018 Apr.

\section{Publisher's Note}

Springer Nature remains neutral with regard to jurisdictional claims in published maps and institutional affiliations.

\section{Ready to submit your research? Choose BMC and benefit from:}

- fast, convenient online submission

- thorough peer review by experienced researchers in your field

- rapid publication on acceptance

- support for research data, including large and complex data types

- gold Open Access which fosters wider collaboration and increased citations

- maximum visibility for your research: over $100 \mathrm{M}$ website views per year

At BMC, research is always in progress.

Learn more biomedcentral.com/submissions 